\title{
The Synthesis of Dimethyl Carbonate by the Oxicarbonylation of Methanol Over Cu Supported on Carbon Norit
}

\author{
G. Merza • B. László · A. Oszkó · G. Pótári • \\ E. Varga $\cdot$ A. Erdőhelyi
}

Received: 26 September 2014/Accepted: 5 December 2014/Published online: 23 December 2014

(c) Springer Science+Business Media New York 2014

\begin{abstract}
The catalytic activity of Norit supported $\mathrm{Cu}, \mathrm{Ni}$ and $\mathrm{Cu}-\mathrm{Ni}$ catalysts was investigated in the synthesis of dimethyl carbonate (DMC) by the oxidative carbonylation of methanol. $\mathrm{Cu} /$ Norit showed the best catalytic activity. The reaction was carried out in a continuous flow system at atmospheric pressure usually at $393 \mathrm{~K}$. The main products were methyl formate, $\mathrm{DMC}$ and $\mathrm{CO}_{2}$. The methanol conversion on $\mathrm{Cu} /$ Norit achieved in steady state was about $22 \%$ and the DMC yield $13.2 \%$. Based on the XPS data we can establish that copper reduced to its metallic form during reduction but oxidized in the reaction mixture, and is mostly in the $\mathrm{Cu}^{+}$state, with some $\mathrm{Cu}^{2+}$. It is possible that the DMC formation rate depends on the surface concentration of oxidized $\mathrm{Cu}$ and on the ratio of $\mathrm{Cu}^{+}$and $\mathrm{Cu}^{2+}$. Based upon the IR measurements adsorbed DMC was found on the surface of the Cu/Norit catalyst during the catalytic reaction.
\end{abstract}

Keywords Oxidative carbonylation - Dimethyl carbonate - Active carbon - Supported $\mathrm{Cu}$ catalyst . $\mathrm{Cu} /$ Norit

\section{Introduction}

As an environmentally friendly compound dimethyl carbonate (DMC) has the potential to be used as a green

G. Merza · B. László · A. Oszkó · G. Pótári · E. Varga ·

A. Erdőhelyi ( $\square)$

Institute of Physical Chemistry and Materials Science,

University of Szeged, Aradi vértanúk tere 1, Szeged 6720,

Hungary

e-mail: erdohelyi@chem.u-szeged.hu industrial chemical. Its usage is facilitated by its low toxicity, high biodegradability and low persistence [1]. DMC can be used in industry mainly as a fuel additive [2], precursor for synthesis of carbonic acid derivatives, methylating agent [3], methyl sulphate exchanger [4], or an intermediate in the synthesis of polycarbonates and isocyanates [5], carbonylating agent [6], alkylating agent, polar solvent [7], component in the synthesis of polyurethane [8].

Proving the possibilities of the green usage of DMC, a new alternative route for the enzymatic coproduction of biodiesel and glycerol carbonate was investigated by Seong et al. [9] by the transesterification of soybean oil with DMC.

The traditional DMC synthesis used toxic and hazardous phosgene as reactant and suffered from several drawbacks [10]. Numerous developments have been published for the production of DMC including methanolysis of phosgene, ester exchange process, liquid phase methanol carbonylation and methylnitrite carbonylation and gas-phase oxidative carbonylation of methanol [11] although these processes use corrosive, toxic and flammable gases.

Therefore the preparation and the usage of new catalysts such as $\mathrm{K}_{2} \mathrm{CO}_{3}$ [12], $\mathrm{ZrO}_{2}$ [13], $\mathrm{H}_{3} \mathrm{PW}_{12} \mathrm{O}_{4}-\mathrm{ZrO}_{2}$ [14], $\mathrm{Cu}$ modified (Ni, V, O) complex [15], $\mathrm{ZrO}_{2}-\mathrm{CeO}_{2}$ [16] were forced. The disadvantages such as the need of high pressure or the deactivation of the catalyst were also described and the reported formation rate of DMC was low. Various environmentally friendly chemical methods were developed like the transesterification of ethylene carbonate with methanol [17], and the synthesis from urea and methanol [18].

Carbonaceous materials have been used widely in catalysis because of their superior structural, mechanical, chemical, thermal, and unique electrical transport properties. 
Among the various catalysts $\mathrm{CuCl}_{2} / \mathrm{NaOH} /$ activated carbon (AC) was reported to show good catalytic performance in the synthesis of DMC. The effect of reaction conditions and that of promoters on the reaction were evaluated [19]. The optimal reaction temperature was set to 393-403 K. The catalytic activity increased with the increase of $\mathrm{OH} / \mathrm{Cu}$ molar ratio as compared to $\mathrm{CuCl}_{2} / \mathrm{AC}$. With the morphological analysis two different crystal structures were observed on the surface of the catalyst: orthorhombic and rhombohedral. The second one was more favourable for DMC synthesis [20].

Typical results were obtained on $\mathrm{CuCl} / \mathrm{Carbon}$ in the oxidative carbonylation of methanol. It is clear that the $\mathrm{CuCl}_{3}{ }^{2-}$ surface species finally shifted to $\mathrm{Cu}^{0}$ and cuprous chloride was identified as the active species in DMC production [21]. Ren et al. [22] observed that the activation temperature of the starch-based carbon supported $\mathrm{Cu}$ catalyst significantly influenced the activity of the sample, while the surface area, micropore volume and the total pore volume changed and these properties resulted in the different efficiency. The $\mathrm{AC}$ supported $\mathrm{PdCl}_{2}-\mathrm{CuCl}_{2}$ was also an efficient catalyst in this reaction but the activity of the sample significantly decreased in time. The results showed that the catalyst deactivation was due to the loss of chlorine [23].

$\mathrm{Cu}-\mathrm{Ni}$ supported on multi-walled carbon nanotubes (MWCNT) was also used as catalyst for the direct synthesis of DMC connected with the full characterization of the sample. Relatively high methanol conversion and DMC selectivity were reported, though the optimal experimental conditions, like high pressure, have some inconveniences [24]. In a recent paper we discussed the yield of DMC formation which was higher on $\mathrm{Cu} / \mathrm{MWCNT}$ than on $\mathrm{Cu}-$ Ni/MWCNT catalyst [25].

On a novel graphene nanosheet (GNS) $\mathrm{Cu}-\mathrm{Ni}$ bimetallic catalyst the catalytically active metal particles were dispersed on the GNS in the direct synthesis of DMC and this effectively enhanced the productivity [26].

The mechanism of the oxidative carbonylation of methanol was theoretically investigated by Ren et al. The calculated results showed that the DMC formation pathway should be as follows: monomethyl carbonate (MMC) species produced by $\mathrm{CO}$ insertion to methoxide species, and then MMC reacts with methanol to form DMC [27].

Earlier AC (Norit) was successfully used as a catalyst support in different reactions. Solymosi et al. used $\mathrm{Mo}_{2} \mathrm{C} /$ Norit in the decomposition and steam reforming of methanol [28], for the decomposition of ethanol [29], and also for the steam reforming and the decomposition of dimethyl ether (DME) [30]. Marbán et al. investigated Norit-supported Rh-based catalyst for the methanol decomposition reaction [31], Tolmacsov et al. tested Pt metals supported on Norit for the decomposition and reforming of methanol
[32]. Nevertheless we did not find any data in the literature about using carbon Norit as catalysts support operating in DMC synthesis.

In this paper we focus on the e synthesis of DMC at atmospheric pressure by vapour-phase oxidative carbonylation of methanol on copper supported by AC (Norit), a chloride free catalyst and on the catalytic properties during the reaction.

\section{Experimental}

\subsection{Preparation of the Catalyst}

Norit supported $\mathrm{Cu}, \mathrm{Cu}-\mathrm{Ni}$ and $\mathrm{Ni}$ catalysts were prepared via the conventional incipient wetness impregnation technique. The AC (Norit ROW $0.8 \mathrm{~mm}$ pellet from Alfa Aesar) was impregnated with $\mathrm{Cu}\left(\mathrm{NO}_{3}\right)_{2} \cdot 3 \mathrm{H}_{2} \mathrm{O}$ or/and $\mathrm{Ni}\left(\mathrm{NO}_{3}\right)_{2} \cdot 6 \mathrm{H}_{2} \mathrm{O}$ solution. In the bimetallic sample the $\mathrm{Cu} /$ $\mathrm{Ni}$ ratio was 2 . In a typical preparation process calculated amount of the metal salt was dissolved in $25 \%$ ammonia solution and then the support was added to yield $10 \mathrm{wt} \%$ metal content. The mixture was stirred for $24 \mathrm{~h}$ at room temperature followed by ultrasonication for $2 \mathrm{~h}$, and aging for $24 \mathrm{~h}$. The liquid was evaporated at $363 \mathrm{~K}$. The dry powder was calcined at $723 \mathrm{~K}$ for $3 \mathrm{~h}$ in $\mathrm{N}_{2}$ flow. The samples were reduced in situ usually at $873 \mathrm{~K}$ in hydrogen flow for $1 \mathrm{~h}$. The BET surface area of the $\mathrm{Cu} / \mathrm{Norit}$ was $1,070 \mathrm{~m}^{2} / \mathrm{g}$, of the $\mathrm{Ni} / \mathrm{Norit} 900 \mathrm{~m}^{2} / \mathrm{g}$, of the $\mathrm{Cu}-\mathrm{Ni} / \mathrm{Norit}$ 951 and $1,212 \mathrm{~m}^{2} / \mathrm{g}$ of the pure support.

The support was originally consisted of $0.8 \mathrm{~mm}$ o.d. and 3-4 mm long cylindrical pellets; this form was kept throughout the experiments. The average size of the metal particles was about $39 \mathrm{~nm}$. Only $6 \%$ of the $\mathrm{Cu}$ particles are smaller than $10 \mathrm{~nm}$ and about $20 \%$ of them are bigger than $50 \mathrm{~nm}$.

The metal clusters were roughly spherical on the surface of amorphous carbon.

\subsection{Reaction Procedure}

The DMC synthesis by the oxidative carbonylation of methanol was carried out in a continuous flow system in a fixed bed quartz reactor at atmospheric pressure. The reactor tube had an inner diameter of $7 \mathrm{~mm}$ with a length of circa $20 \mathrm{~cm}$.

Methanol was introduced into the system by bubbling the mixture of $\mathrm{CO}$ and $\mathrm{O}_{2}$ through the methanol at $323 \mathrm{~K}$. Usually $1 \mathrm{~g}$ of the catalyst was used without dilution. After the pre-treatment of the sample the reactor was cooled down to the reaction temperature, usually $393 \mathrm{~K}$. The ratio of the reactants $\left(\mathrm{CH}_{3} \mathrm{OH} / \mathrm{CO} / \mathrm{O}_{2}\right.$ ratio was $\left.2 / 1 / 1\right)$ was the same in all experiments. The flow rate was usually $16 \mathrm{ml} / \mathrm{min}$. 
The reactants and the products were analysed on-line by an Agilent 6890 gas chromatograph equipped with an Agilent 5975C VL MSD mass-spectrometer, thermal conductivity and flame ionization detectors.

\subsection{Characterization of the Catalysts}

For XPS studies the powder samples were pressed into tablets with approximately $10 \mathrm{~mm}$ diameter and a few tenth of mm thickness and placed into the load lock of the spectrometer. Sample treatments were carried out in a high pressure cell (catalysis chamber) directly attached to the analysing chamber and isolated from that with a gate valve. With the help of the sample manipulator and a second insertion mechanism it was possible to transfer the samples from the analysis chamber into the high pressure cell in vacuum, without the reach of air. The samples were pretreated the same way as mentioned above. After each pretreatment step the samples were cooled down in nitrogen flow to room temperature. Afterwards the flow was stopped, the high pressure cell was evacuated and the sample was taken back to the analysis chamber. XP spectra were taken with a SPECS instrument equipped with a PHOIBOS 150 MCD 9 hemispherical energy analyser operated in the FAT mode. The excitation source was the $\mathrm{K}_{\alpha}$ radiation of a magnesium anode $(\mathrm{h} v=1,253.6 \mathrm{eV})$. The $\mathrm{X}$-ray gun was operated at $210 \mathrm{~W}$ power $(14 \mathrm{kV}, 15 \mathrm{~mA})$. The pass energy was set to $20 \mathrm{eV}$, the step size was $25 \mathrm{meV}$. Typically five scans were added to get a single spectrum. For data acquisition and evaluation both manufacturers' (Specslab2) and commercial (CasaXPS, Origin) software packages were used.

Infrared spectra were recorded with an Agilent Cary 670 type FTIR spectrometer equipped with diffuse reflectance attachment (Harrick) with $\mathrm{BaF}_{2}$ windows with a wave number accuracy of $\pm 4 \mathrm{~cm}^{-1}$. Typically 32 scans were registered. The whole optical path was purged by $\mathrm{CO}_{2}$ - and $\mathrm{H}_{2} \mathrm{O}$-free air generated by a Balston purge gas generator. The catalysts were pre-treated as mentioned above then the $\mathrm{CH}_{3} \mathrm{OH}+\mathrm{CO}+\mathrm{O}_{2}$ mixture was introduced into the cell at the reaction temperature and the IR spectra were recorded. Practically the same experimental conditions were used as in the catalytic measurements.

The BET surface areas of the catalysts were measured using $\mathrm{N}_{2}$ adsorption at the temperature of the liquid nitrogen by a BELCAT A instrument with single point method.

The $\mathrm{Cu}$ particle size distribution was determined by image analysis of the HRTEM (FEI Tecnai $\mathrm{G}^{2} 20$ X-Twin; $200 \mathrm{kV}$ operation voltage, $180,000 \times$ magnification, $125 \mathrm{pm} /$ pixel resolution) pictures using the ImageJ software. At least five representative images of equal magnification, taken at different spots of the TEM grid were first subjected to rolling ball background subtraction and contrast enhancement, and then the diameter of the metal nanoparticles in the image was manually measured against the calibrated TEM scale bar. Each diameter distribution histogram was constructed from 100 individual nanoparticle diameter measurements $[33,34]$.

\section{Results and Discussion}

\subsection{Oxidative Carbonylation of Methanol}

The catalytic reaction was intentionally performed at atmospheric pressure at $393 \mathrm{~K}$, on $\mathrm{Cu} /$ Norit to obtain a 'greener' way for DMC synthesis. For comparison the tests were carried out also on $\mathrm{Ni} / \mathrm{Norit}$ and on $\mathrm{Cu}-\mathrm{Ni} / \mathrm{Norit}$ catalysts.

In the reactions $\mathrm{CO}_{2}, \mathrm{DMC}$ and methyl formate (MF) were formed as main products in all cases. A small amount of dimethoxy methane (DMM) and traces of DME were also detected. Figure 1a shows the conversion of methanol on $\mathrm{Cu} / \mathrm{Norit}$, which was increasing through the reaction, up to $22 \%$ after $7 \mathrm{~h}$ time on stream. Figure $1 \mathrm{~b}$ demonstrates that on $\mathrm{Ni} /$ Norit the methanol conversion was about $13 \%$ at the beginning of the reaction, in the first $2 \mathrm{~h}$ it decreased continuously and after $150 \mathrm{~min}$ reached the quasi steady state value, about $2.5 \%$. The conversion of methanol on $\mathrm{Cu}-\mathrm{Ni} / \mathrm{Norit}$ increased up to $11 \%$ in the first $130 \mathrm{~min}$ of the reaction attained a maximum and remained nearly the same (Fig. 1c). The CO conversion changed similarly to the methanol conversion in all cases. On the Ni/Norit it decreased in time but in the $\mathrm{Cu}$ containing samples the conversion increased as a function of time on stream (Fig. 1).

On $\mathrm{Cu} / \mathrm{Norit}$ the formation rate of $\mathrm{CO}_{2}$ in the first hour of the reaction increased, then decreased, after $3 \mathrm{~h}$ it remained nearly constant, while the formation rate of MF slightly increased in the first hour then remained the same (Fig. 2a). The formation of DMC started after the 100th min of the reaction evolved with an enhanced rate until the 350th min afterwards started to decrease. On Ni/Norit the rate of $\mathrm{MF}$ and $\mathrm{CO}_{2}$ formation decreased in time, the $\mathrm{DMC}$ formation increased slightly at the same time although the production was less than measured on Cu/Norit (Fig. 2b). However, on $\mathrm{Cu}-\mathrm{Ni} / \mathrm{Norit}$ the rate of $\mathrm{MF}$ production significantly increased and that of $\mathrm{CO}_{2}$ decreased slower in time, still the DMC and the DMM formation increased only a bit (Fig. 2c). It is clear from the above data, that under the same circumstances the rate of DMC formation was more than ten times higher on $\mathrm{Cu} / \mathrm{Norit}$ as on $\mathrm{Ni} / \mathrm{Norit}$ or on $\mathrm{Cu}-$ $\mathrm{Ni} /$ Norit after $5 \mathrm{~h}$ of the reaction.

The selectivity of MF remarkably increased at the beginning of the reaction on $\mathrm{Cu} /$ Norit. After reaching a 
Fig. 1 The conversion of CO and methanol on $\mathrm{Cu} / \mathrm{Norit}(\mathbf{a})$, Norit $(\mathbf{c})$ in the $\mathrm{CH}_{3} \mathrm{OH}+\mathrm{CO}+\mathrm{O}_{2}(2: 1: 1)$ reaction at $393 \mathrm{~K}$, (The space velocity was $780 \mathrm{~h}^{-1}$ ) on $\mathrm{Cu}-\mathrm{Ni} / \mathrm{Norit}(\mathbf{b})$ and on $\mathrm{Ni} /$
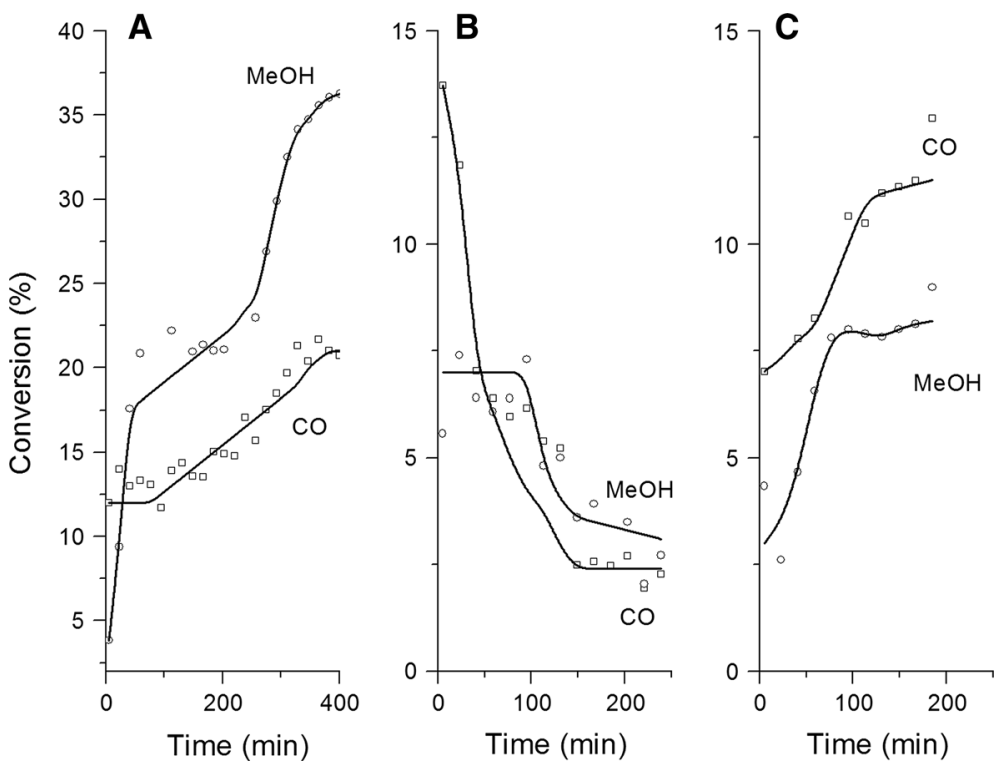

Fig. 2 The rate of dimethyl carbonate, methyl formate, $\mathrm{CO}_{2}$ and dimethoxy methane formation on $\mathrm{Cu} / \mathrm{Norit}$ (a), on $\mathrm{Ni} / \mathrm{Norit}$ (b) and on $\mathrm{Cu}-\mathrm{Ni} /$ Norit (c) in the $\mathrm{CH}_{3} \mathrm{OH}+\mathrm{CO}+\mathrm{O}_{2}(2: 1: 1)$ reaction at $393 \mathrm{~K}$, (The space velocity was $780 \mathrm{~h}^{-1}$ )
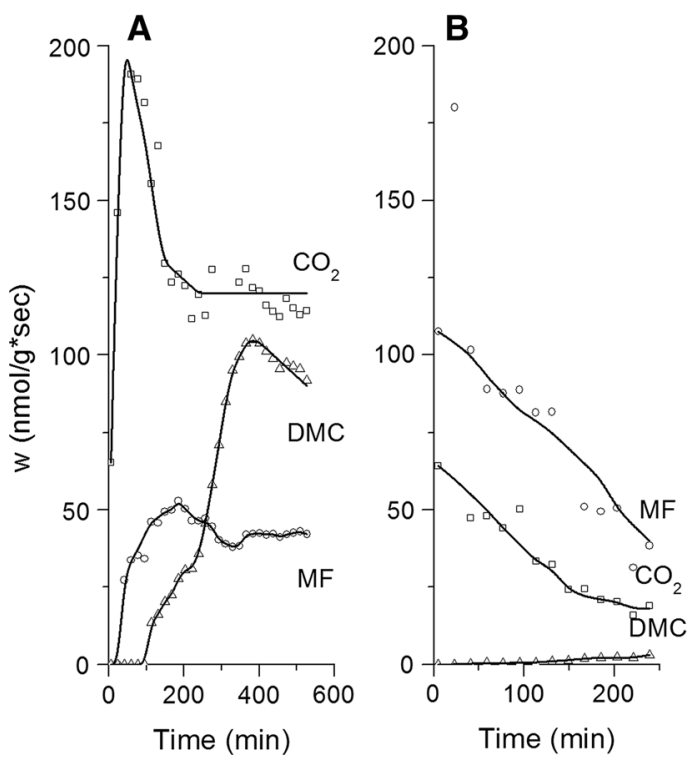

maximum $33 \%$ MF selectivity after $150 \mathrm{~min}$ it started to decrease and stabilized after $300 \mathrm{~min}$ at $17 \%$. In the first $100 \mathrm{~min}$ of the reaction only traces of DMC was formed then its selectivity increased gradually, after $300 \mathrm{~min}$ stayed nearly constant, about $60 \%$. On the other hand, $\mathrm{CO}_{2}$ formation was the opposite, decreased drastically from $100 \%$ selectivity to $23 \%$ after $300 \mathrm{~min}$ (Fig. 3a).

On Ni/Norit the MF (from 90 to $74 \%$ ) and the $\mathrm{CO}_{2}$ (from 22 to $19 \%$ ) selectivity decreased (Fig. 3b). In the first 100-120 min of the reaction only a small amount of DMC was detected, afterwards with increasing selectivity it reached only $10 \%$ in the $250 \mathrm{~min}$ of the reaction. Figure $3 \mathrm{c}$ shows the selectivity of the products on $\mathrm{Cu}-\mathrm{Ni}$ / Norit. DMC selectivity marginally and that of MF notably increased in the reaction, while the selectivity of $\mathrm{CO}_{2}$ constantly decreased.

The yield of the DMC formation was the highest in the steady state period at ambient pressure on $\mathrm{Cu} /$ Norit $(\sim 13.2 \%)$ and it decreased in the order of $\mathrm{Cu} / \mathrm{Nor}$ it $>\mathrm{Cu}-\mathrm{Ni} / \mathrm{Norit}>\mathrm{Ni} / \mathrm{Norit}$. The value obtained on $\mathrm{Cu} /$ Norit is comparable with the yield obtained on $\mathrm{Cu} / \mathrm{Y}$ zeolite $(13.1 \%)$ [35] or on $\mathrm{CuCl}_{2}$ supported on $\mathrm{AC}(16.3 \%)$ [19] at 2.3 bar in an autoclave system, but it was definitely higher than it was found on $\mathrm{Cu}-\mathrm{Ni} / \mathrm{MWCNT}$ at high pressure [12] or on $\mathrm{Cu} / \mathrm{MWCNT}$ at atmospheric pressure [25].

When the catalyst was reduced at lower temperature (773 or $673 \mathrm{~K}$ ) the induction time of DMC formation was 
Fig. 3 The selectivity of dimethyl carbonate, methyl formate, $\mathrm{CO}_{2}$ and dimethoxy methane on $\mathrm{Cu} / \mathrm{Norit}(\mathbf{a})$, on $\mathrm{Ni} /$ Norit (b) and on $\mathrm{Cu}-\mathrm{Ni} / \mathrm{Norit}$ (c) in the $\mathrm{CH}_{3} \mathrm{OH}+\mathrm{CO}+\mathrm{O}_{2}$ (2:1:1) reaction at $393 \mathrm{~K}$, (The space velocity was $780 \mathrm{~h}^{-1}$ )

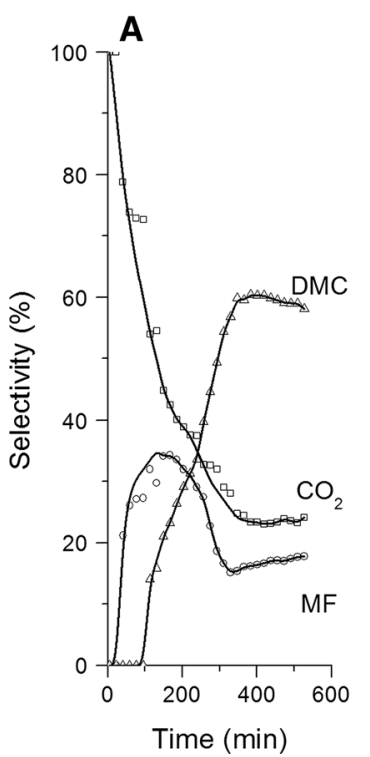

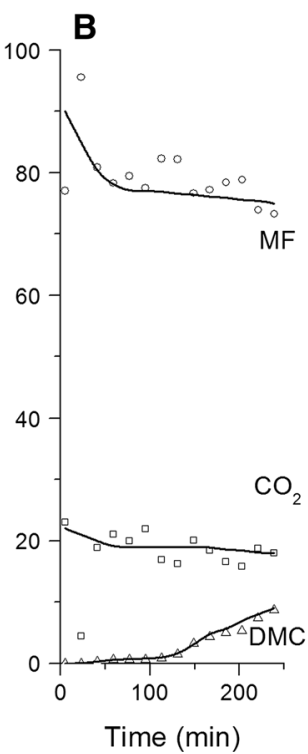

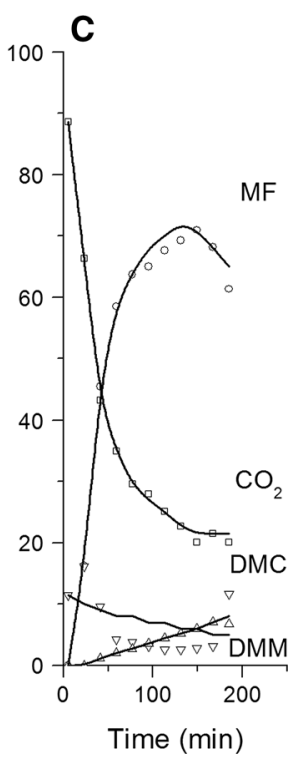

considerably longer (after the pre-treatment at $673 \mathrm{~K}$ it was $280 \mathrm{~min}$ ), the DMC selectivity in the steady state was lower, below $20 \%$ instead of $60 \%$. Without any pre-treatment the catalyst was totally inactive in the DMC synthesis.

When the methanol-oxygen reaction was followed under the same experimental conditions at $393 \mathrm{~K}$, the methanol conversion was similar on either of the catalysts though in these cases MF was the main product, only a small amount of $\mathrm{CO}_{2}$ and traces of formaldehyde were formed. The rate of products formation decreased in the first $30 \mathrm{~min}$ of the reaction then remained stable. In the methanol-CO reaction only $\mathrm{CO}_{2}$ was formed.

The pure support was also used as catalyst in the same reaction using the same experimental conditions. In this case only a small amount of $\mathrm{CO}_{2}$ was found as reaction product.

\subsection{Catalytic Behaviour of $\mathrm{Cu} /$ Norit}

The oxidative carbonylation of methanol was studied in detail on $\mathrm{Cu} / \mathrm{Norit}$. The reaction temperature was varied from 373 to $413 \mathrm{~K}$. Each experiment was carried out on fresh catalyst. The steady state values obtained at different temperatures were compared. The rate of the products formation increased in all cases when the reaction was followed at higher temperature than $373 \mathrm{~K}$. The amount of $\mathrm{CO}_{2}$ increased continuously as a function of temperature but the MF and DMC formation curves had maxima at 383 and $393 \mathrm{~K}$, respectively (Fig. 4a). It should be noted that the DMM formation rate significantly increased as a function of temperature; at $413 \mathrm{~K}$ it was about the quarter of the DMC production, while only traces were detected at $373 \mathrm{~K}$. The selectivity of MF decreased by increasing the temperature, while that of DMC changed by giving a maximum curve.
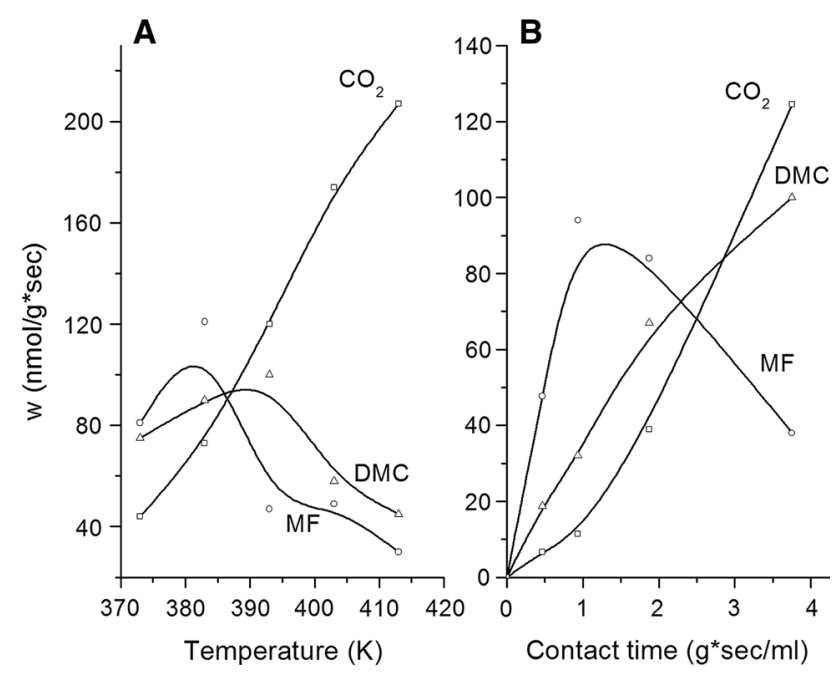

Fig. 4 The formation rate of $\mathrm{CO}_{2}$, dimethyl carbonate and methyl formate as a function of temperature (a) (contact time $=3.75 \mathrm{~g} \mathrm{sec} /$ $\mathrm{ml})$ and contact time (b) at $393 \mathrm{~K}$ in the $\mathrm{CH}_{3} \mathrm{OH}+\mathrm{CO}+\mathrm{O}_{2}(2: 1: 1)$ reaction on $\mathrm{Cu} /$ Norit approximately at the steady state conditions

The variation of the space velocity exerted divergent influence on the products distribution of the oxidative carbonylation of methanol. The conversion of methanol and the amount of $\mathrm{DMC}$ and $\mathrm{CO}_{2}$ formed in the reaction increased quasi linearly with rising the contact time. In contrast the formation curve of MF had a maximum (Fig. 4b).

\subsection{XP Spectra}

In order to follow the changes of the surface composition and those of the oxidation states of the catalysts components XPS measurements were carried out during the catalytic reaction. 
High-resolution XP spectra of $\mathrm{Cu} /$ Norit were taken in the $\mathrm{Cu} 2 \mathrm{p}, \mathrm{C} 1 \mathrm{~s}, \mathrm{O} 1 \mathrm{~s}$ and $\mathrm{Cu}$ LMM regions in all stages of the treatment. The $\mathrm{Cu} 2 \mathrm{p}$ doublet in the as received sample with $\mathrm{Cu} 2 \mathrm{p}_{3 / 2}$ at $933.6 \mathrm{eV}$ showed the presence of $\mathrm{Cu}\left(\mathrm{NO}_{3}\right)_{2}$ [36] and $\mathrm{CuO}$ which probably formed in the decomposition of nitrate salt. Both the position of the $\mathrm{Cu}$ $2 p_{3 / 2}$ peak and the presence of satellite features support this assertion. The peak location shifted to $932.4 \mathrm{eV}$ after reduction at $873 \mathrm{~K}$ for $60 \mathrm{~min}$ and the satellites disappeared (Fig. 5). To distinguish between different copper oxidation states we must also take into account the Auger parameter, which in its simplified form of the sum of the binding energy of the $\mathrm{Cu} 2 \mathrm{p}_{3 / 2}$ photo peak and the kinetic energy of the $\mathrm{L}_{3} \mathrm{MM}$ Auger peak. This feature was located at $918.8 \mathrm{eV}$ after reduction, thus giving $1,851.2 \mathrm{eV}$ for the Auger parameter, so copper reduced to its metallic form and its surface concentration significantly increased during the reduction. In the course of the oxidative carbonylation of methanol the $\mathrm{Cu} 2 \mathrm{p}_{3 / 2}$ binding energy and the peak intensity did not change but the enhancement of a new peak around $944 \mathrm{eV}$ (as a satellite) could be seen. This peak was observed even after $10 \mathrm{~min}$ of the reaction. After $60 \mathrm{~min}$ an intensifying shoulder could also be observed on the high binding energy side on both components of the $\mathrm{Cu} 2 \mathrm{p}$ doublet. The Auger spectra were more similar to the one taken in the as received state than to the spectrum taken after reduction. So we may conclude that copper was oxidized in the reaction mixture and was mostly in the $\mathrm{Cu}^{+}$ state, with some $\mathrm{Cu}^{2+}$ also present on the surface. The amount of this latter species increased with increasing reaction time and was demonstrated by the intensifying satellite peak and shoulder on the copper spectra.

Similar spectra were obtained for the $\mathrm{Cu}$ component in the $\mathrm{Cu}-\mathrm{Ni} /$ Norit catalyst. As regards the binding energy of $\mathrm{Ni} 2 \mathrm{p}$ in the as received sample the presence of $\mathrm{NiO}$ $(855.6 \mathrm{eV})$ and a small amount of metallic $\mathrm{Ni}(852.7 \mathrm{eV})$ [37] were detected. The $\mathrm{Ni} 2 \mathrm{p}$ spectra of the reduced catalyst showed the presence of metallic $\mathrm{Ni}$ and $\mathrm{Ni}^{2+}$ species at 852.7 and $855.6 \mathrm{eV}$, respectively. This indicates the existence of a fraction of unreduced $\mathrm{Ni}$ after the reduction of the sample in the $\mathrm{Cu}-\mathrm{Ni} / \mathrm{Norit}$. On the Ni/Norit sample before the pre-treatment only the $\mathrm{Ni}^{2+}$ was detected at $855.6 \mathrm{eV}$. On the reduced sample a new feature was also observed at $854.5 \mathrm{eV}$ in addition to the metallic $\mathrm{Ni}$ $(852.7 \mathrm{eV})$ which could be assigned also to $\mathrm{Ni}^{2+}$ but in different chemical environment [38].

The survey spectra showed a very intense C 1s peak. High resolution carbon spectra taken on pure Norit and $\mathrm{Cu}$ /Norit featured a narrow asymmetric peak $(\mathrm{FWHM}=1.3-1.4 \mathrm{eV})$ with a characteristic long tailing and shoulder on the high binding energy side (Fig. 6). On pure Norit an intense peak showed up at $284.5 \mathrm{eV}$ in the as received state with components at $\sim 286-287, \sim 290$ and $\sim 293 \mathrm{eV}$. The $284.5 \mathrm{eV}$ peak corresponds to $\mathrm{C}-\mathrm{C}$ and
Fig. 5 XP spectra of $\mathrm{Cu} 2 \mathrm{p}$ (a) and $\mathrm{Cu}$ LMM Auger spectra

(b) recorded after the

$\mathrm{CH}_{3} \mathrm{OH}+\mathrm{CO}+\mathrm{O}_{2}$ reaction at $393 \mathrm{~K}$ on $\mathrm{Cu} / \mathrm{Norit}$; as received (1), reduced sample (2), after 10 th (3), 60th (4) and 150th (5) minutes of the reaction
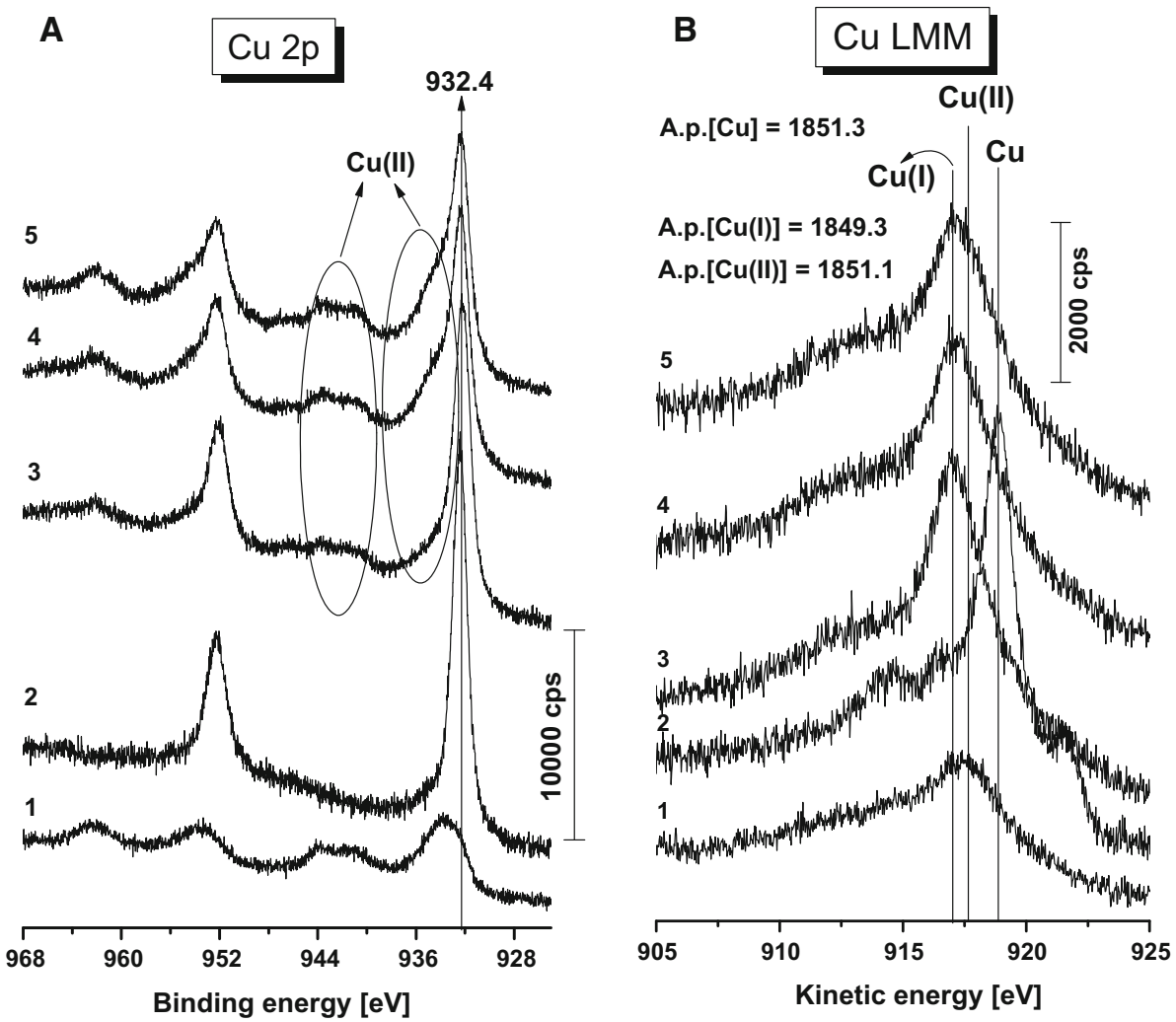
C-H bonds, while the 286 and $290 \mathrm{eV}$ peaks to oxygenated carbon bonds like $\mathrm{C}-\mathrm{O}$ (phenolic, alcoholic, etheric) and $\mathrm{O}-\mathrm{C}=\mathrm{O}$ (carboxyl, ester), respectively. The component with the highest binding energy may come from adsorbed $\mathrm{CO}$ or $\mathrm{CO}_{2}$ or from the shake-up satellites from the $\pi-\pi^{*}$ transitions in aromatic rings [39, 40].

No changes were detected on pure Norit after a mild reduction with $\mathrm{H}_{2}$ at $473 \mathrm{~K}$ for $30 \mathrm{~min}$. The peak shape and peak areas remained practically constant throughout the experiment on the copper doped samples too; the change was well within $10 \%$. However the intensity of the component representing $\mathrm{C}-\mathrm{O}$ groups markedly decreased. These also mean that we could not detect the formation of any new carbonaceous surface species during the reaction. The copper doublet is easily identifiable on the wide scan spectra but the $\mathrm{O} 1 \mathrm{~s}$ region is hardly discernible, especially on the spectra of the treated samples. However high-resolution $\mathrm{O} 1 \mathrm{~s}$ spectra showed that this region has a complex shape. In the $\mathrm{O} 1 \mathrm{~s}$ region of pure Norit a peak located at $532.5 \mathrm{eV}$ was detected with a shoulder at $537.4 \mathrm{eV}$. After reduction the intensity of the main peak reduced but its position did not change. The minor component shifted to $536.3 \mathrm{eV}$ and its intensity increased relative to the main peak. The picture modified when spectra were recorded on $\mathrm{Cu} / \mathrm{Norit}$ after reduction at $693 \mathrm{~K}$ for $60 \mathrm{~min}$. In this case the $\mathrm{O} 1 \mathrm{~s}$ spectrum could be fitted with four components, the most intense one being located at $533.2 \mathrm{eV}$ (Fig. 7.). At the same time two minor shoulders could be identified at 536.6 and $530.6 \mathrm{eV}$. The peak fitting process required to suppose that an additional component is present peaking at 534.4.
After the oxidative carbonylation of methanol the line shape changed considerably, an intense peak developed around $530-531 \mathrm{eV}$ even after $10 \mathrm{~min}$ time on stream but there was no change in the intensity during the reaction. The rendering of oxygen components is somewhat ambiguous in the literature. Some [39-41] assign the peak around $530-531 \mathrm{eV}$ to oxygen in $\mathrm{C}=\mathrm{O}$ bond, while SoriaSánchez et al. put this component to $531.7 \mathrm{eV}$ [42]. Since $\mathrm{C}=\mathrm{O}$ bonds can occur in various groups at the edges of the carbon structure, both assumptions can be true. Electrons from copper-oxygen bonds can also contribute to this peak. Following the work of Figueiredo et al. [39] the peak at 533.2 after reduction can be attributed to $-\mathrm{O}-$ bonds. This peak vanished in the course of reaction, instead peaks developed at $532.7-532.9 \mathrm{eV}$, with increasing intensity during the reaction, characteristic of $\mathrm{C}=\mathrm{O}$ bonds e.g. in anhydride. $\mathrm{OH}$ groups may also contribute to this feature. The peak at 534.0-534.4 eV may originate from carboxylic groups, while that at 536.1-536.6 eV was from adsorbed water. As already mentioned above, neither the intensity nor the shape of the $\mathrm{C} 1 \mathrm{~s}$ spectrum changed remarkably during the reaction. Changes did occur in the structure of $\mathrm{O}$ 1s spectra however these are not reflected in the carbon line shapes. The reason for this was that after reduction on the sample the carbon to oxygen ratio at the surface was about 20:1. After $150 \mathrm{~min}$ of the reaction the oxygen content doubled to about $10 \%$, but this was still too few to cause major changes in the carbon spectra.

From the XP spectra the surface concentrations of metals on the pre-treated samples were also determined. On
Fig. 6 XP spectra of $\mathrm{C} 1 \mathrm{~s}$ recorded after the $\mathrm{CH}_{3} \mathrm{OH}+\mathrm{CO}+\mathrm{O}_{2}$ reaction at $393 \mathrm{~K}$ on $\mathrm{Cu} / \mathrm{Norit}$; as received (1), reduced sample (2), after 10th (3), 60th (4) and 150th (5) minutes of the reaction $(\mathbf{a})$, the pure Norit (b)
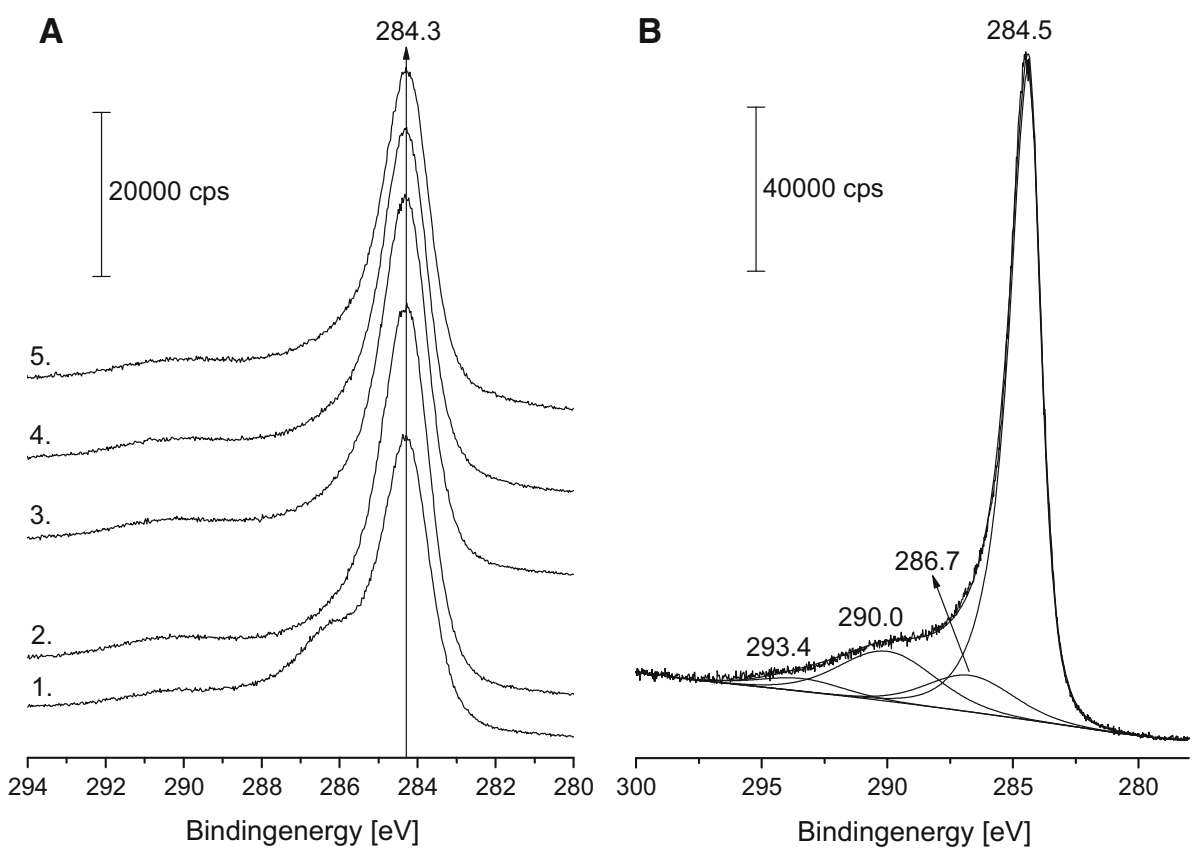
Fig. 7 XP spectra of $\mathrm{O} 1 \mathrm{~s}$ taken on $\mathrm{Cu} / \mathrm{Norit}$; reduced (a), after 10th (b), 50th (c) and 150th

(d) minutes of the $\mathrm{CH}_{3} \mathrm{OH}+\mathrm{CO}+\mathrm{O}_{2}$ reaction at $393 \mathrm{~K}$

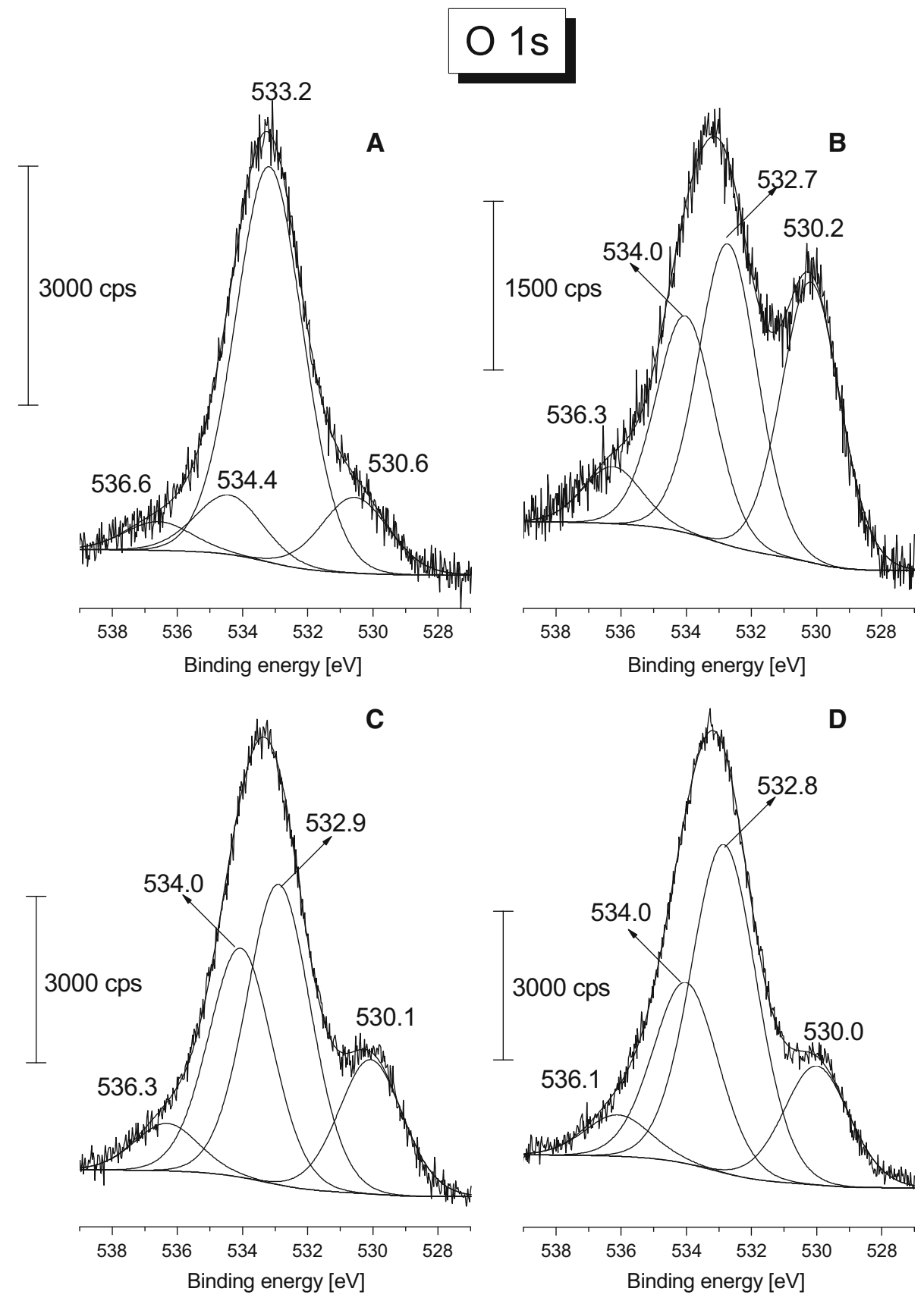

reduced $\mathrm{Cu} / \mathrm{Norit}$ the $\mathrm{Cu}$ content was $0.8 \%$, on $\mathrm{Cu}-\mathrm{Ni}$ / Norit $2 \% \mathrm{Cu}$ and $4.8 \% \mathrm{Ni}$ was detected. On the surface of $\mathrm{Ni} /$ Norit the metal concentration was $6.2 \%$.

\subsection{DRIFT Spectra Registered During the Reaction}

The infrared spectra recorded in the DRIFT cell during the oxidative carbonylation of methanol on $\mathrm{Cu} / \mathrm{Norit}$ at $393 \mathrm{~K}$ showed mainly the gas phase spectra of $\mathrm{CO}$ and methanol. If the spectra obtained on pure Norit under the same experimental conditions in the $2,200-1,000 \mathrm{~cm}^{-1}$ range is subtracted, absorptions at 2,141, 1,767, 1,610, 1,495, 1,404, 1,293-1,291, 1,066-1,053, 1,036-1,034 and 1,026-1,021 cm $\mathrm{cm}^{-1}$ could be detected. The intensities of these bands changed in different ways during the reaction. The absorption at $2,141 \mathrm{~cm}^{-1}$ diminuted, and the 1,767 and $1,292 \mathrm{~cm}^{-1}$ features intensified in time. The intensity of the bands at 1,034 and $1,021 \mathrm{~cm}^{-1}$ first evolved, but after $30 \mathrm{~min}$ of the reaction diminished (Fig. 8).

The bands at $2,141 \mathrm{~cm}^{-1}$ are in the $\mathrm{CO}$ region. In contrast to earlier findings, the adsorption of $\mathrm{CO}$ on $\mathrm{Cu}^{2+}$ or on metallic $\mathrm{Cu}$ sites were predominantly weak and 
reversible at $300 \mathrm{~K}$ and above, still $\mathrm{CO}$ bonded most strongly on $\mathrm{Cu}^{+}[43,44]$. London and Bell [45] found a sharp peak at $2,140 \mathrm{~cm}^{-1}$ during the adsorption of $\mathrm{CO}$ on $\mathrm{CuO}$, but Engeldinger et al. [39] observed the characteristic $\mathrm{Cu}(\mathrm{I})-\mathrm{CO}$ band at $2,060-2,146 \mathrm{~cm}^{-1}$ on $\mathrm{Cu}-\mathrm{Y}$ depending upon the $\mathrm{Cu}$ content. Our XPS results demonstrated that $\mathrm{Cu}^{+}$and $\mathrm{Cu}^{2+}$ also exist on the surface of the catalyst. Based on these results we cannot unambiguously assign this peak. The intensity of the absorption at $2,141 \mathrm{~cm}^{-1}$ minimised in time during the reaction and according to the XPS results the amount of $\mathrm{Cu}^{2+}$ grew on the surface, we may conclude that the $\mathrm{CO}$ absorbs at $2,141 \mathrm{~cm}^{-1}$ and is bonded rather to $\mathrm{Cu}^{+}$than to $\mathrm{Cu}^{2+}$.

In order to assignate the bands formed during the reaction below $2,000 \mathrm{~cm}^{-1}$ we registered the infrared spectra of the main products on $\mathrm{Cu} /$ Norit catalyst. After the adsorption of DMC at room temperature bands were observed in the $2,000-1,100 \mathrm{~cm}^{-1}$ region at $1,781,1,768,1,462,1,454$, $1,293 \mathrm{~cm}^{-1}$. Similar spectra were recorded after the adsorption of DMC on multi-walled carbon nanotube supported $\mathrm{Cu}$ sample [25]. The bands at 1,781 and $1,768 \mathrm{~cm}^{-1}$ could be attributed to $v(\mathrm{C}=\mathrm{O})$, those at 1,462 and $1,454 \mathrm{~cm}^{-1}$ to $\delta_{\text {as }}\left(-\mathrm{CH}_{3}\right)$ in the cis-trans and cis-cis structure of DMC. The intensive absorption at $1,293 \mathrm{~cm}^{-1}$ could be assigned to the $v_{\text {as }}(\mathrm{O}-\mathrm{C}-\mathrm{O})$ vibration. Kar et al. [46] and Bohets and van der Veken [47] used a similar assignation for identifying the absorption bands obtained after DMC adsorption. In the 2,000 and $1,100 \mathrm{~cm}^{-1}$ region in the spectra of MF adsorbed on Cu/Norit between peaks were detected at 1,768,1,754 and $1,743 \mathrm{~cm}^{-1}$ and a weak absorption was observed at $1,208 \mathrm{~cm}^{-1}$. According to
Wilmhurst [48] the bands between 1,740 and $1,770 \mathrm{~cm}^{-1}$ could be assigned as the $\mathrm{C}=\mathrm{O}$ vibration of gas phase MF. Although both DMC and MF have absorption in this region, and an intense band was detected at $1,293-1,291 \mathrm{~cm}^{-1}$ but when MF was adsorbed only a weak absorption was detected at $1,230 \mathrm{~cm}^{-1}$ [48]. From these data we may suppose that the bands at 1,767 and $1,293-1,291 \mathrm{~cm}^{-1}$ showed the presence of DMC on the surface of the catalyst.

The features at 1,459 and $1,404 \mathrm{~cm}^{-1}$ detected at the beginning of the reaction are in the $\mathrm{C}-\mathrm{H}$ deformation region and can be attributed to the anti-symmetric vibration of $\mathrm{CH}_{3}$ and $\mathrm{CH}_{2}$ groups of DMM, respectively [49].

The band at $1,610 \mathrm{~cm}^{-1}$ is due to the adsorbed water formed in the reaction.

The interaction of $\mathrm{CH}_{3} \mathrm{OH}$ and $\mathrm{Cu}$ is summarised briefly for the assignation of the bands below $1,100 \mathrm{~cm}^{-1}$. Previous studies demonstrated that methanol interacted weakly on clean $\mathrm{Cu}$ surface. It is necessary to activate the surface by partial oxidation; $20 \%$ surface coverage by oxygen was required to achieve the maximum adsorption of methanol [50]. Methanol was found to adsorb dissociative on $\mathrm{Cu}^{+}$by the formation of methoxy species without additional supply of oxygen [44]. These findings demonstrate that the activation of methanol and $\mathrm{CO}$ occurs on the same sites, on $\mathrm{Cu}^{+}$. The methanol adsorbed on $\mathrm{Cu}_{2} \mathrm{O}$ produces bands at 1,064 and $1,030 \mathrm{~cm}^{-1}$ that was attributed to the $\mathrm{C}-\mathrm{O}$ stretching and $\mathrm{CH}_{3}$ rocking mode of methoxy, respectively [51]. According to these results the bonds observed at 1,068 an $1,036 \mathrm{~cm}^{-1}$ could be assigned to the $\mathrm{C}-\mathrm{O}$ stretching and $\mathrm{CH}$ rocking mode of methoxy
Fig. 8 Infrared spectra registered during the $\mathrm{CH}_{3}+\mathrm{CO}+\mathrm{O}_{2}$ reaction at $393 \mathrm{~K}$ on $\mathrm{Cu} / \mathrm{Norit}$ in the 10th (1), 20th (2), 30th (3), 90th (4) and 150th (5) minutes

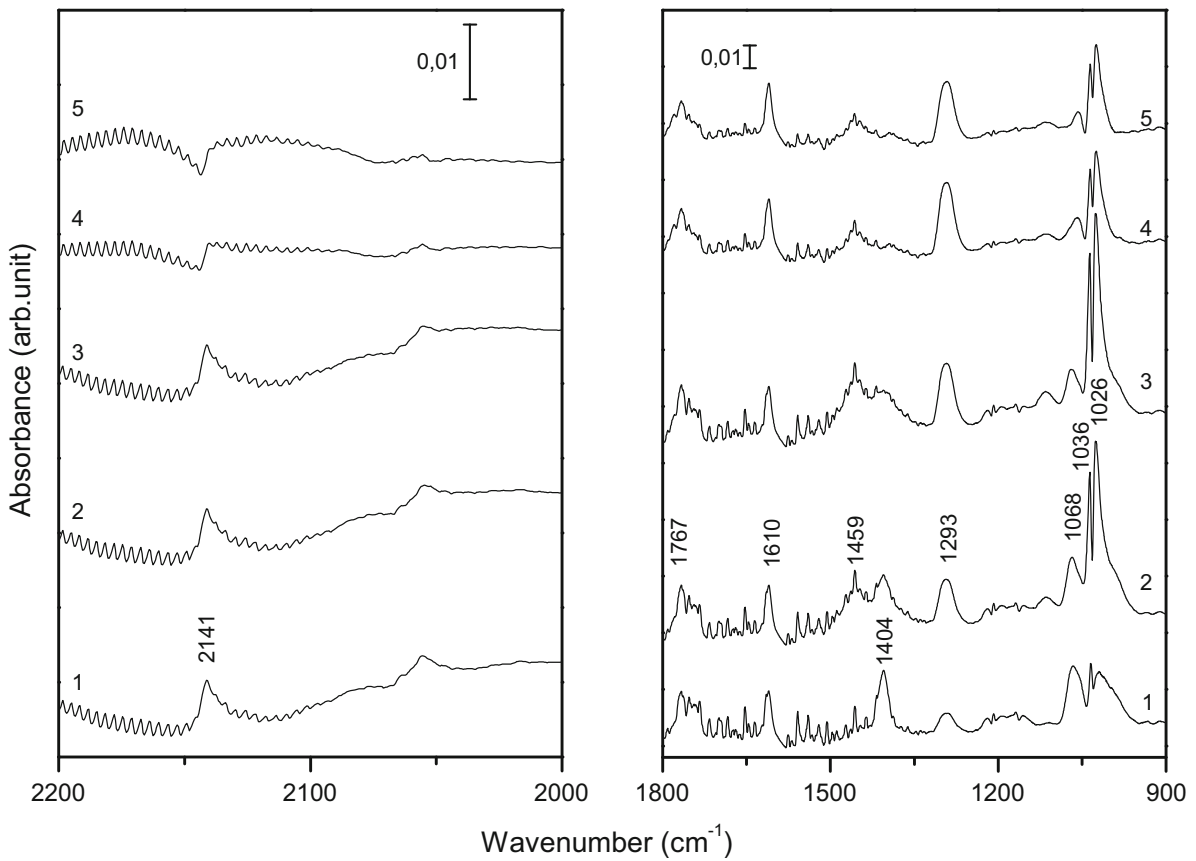


bonded to the oxidized $\mathrm{Cu}$. Methoxy on $\mathrm{Cu}$ (100) surface reportedly absorb at $984 \mathrm{~cm}^{-1}$ at $210 \mathrm{~K}$ [52], the $\mathrm{C}-\mathrm{O}$ lies perpendicular to the surface. The band observed at $1,021-1,026 \mathrm{~cm}^{-1}$ could be attributed to the $\mathrm{C}-\mathrm{O}$ stretching vibration of $\mathrm{CH}_{3}-\mathrm{O}$ bonded to another structure.

\subsection{The Possible Route of DMC Formation}

$\mathrm{Cu} /$ Norit showed remarkable catalytic properties in the oxidative carbonylation of methanol. The methanol conversion reached $22 \%$ during the reaction, the $\mathrm{CO}$ conversion changed as the methanol conversion (Fig. 1a). The $\mathrm{CO}_{2}$ formation rate first increased, then decreased, finally remained nearly constant. The MF formation rate after $100 \mathrm{~min}$ of the reaction remained quasi the same. The DMC formation started only after a 100 min induction period followed by a rapid formation until reaching the steady state (Fig. 2a).

XPS results showed that the reduced catalyst was oxidized in the reaction, thus the surface $\mathrm{Cu}$ was oxidized to $\mathrm{Cu}^{+}$and $\mathrm{Cu}^{2+}$ (Fig. 5) and the amount of the latter species increased with increasing reaction time. The XPS studies of the pure Norit reveals that there was no significant change taking place on the surface of the support (Fig. 6) although the recorded $\mathrm{O} 1 \mathrm{~s}$ spectra showed the change of the oxygen content of the catalyst (Fig. 7).

Infrared measurements revealed that the $\mathrm{CO}$ absorption is more favourable on $\mathrm{Cu}^{+}$than on $\mathrm{Cu}^{2+}$ and that the activation of methanol is also occurring on $\mathrm{Cu}^{+}$.

Earlier it was shown that $\mathrm{Cu}^{+}$ions are the active species in the DMC formation by oxidative carbonylation $[6,16]$. A large number of experimental studies about the mechanism and kinetics of $\mathrm{DMC}$ formation on $\mathrm{CuCl}[3,6,16]$ or on $\mathrm{Cu}$-zeolites [49] have been reported. DMC formation was stated to occur via two possible pathways. One of them is the $\mathrm{CO}$ addition to di-methoxide species, the other is the reaction of MMC and methanol to produce DMC [49].

In a theoretical investigation of the DMC formation on $\mathrm{AC}$ the reaction species were presented to be adsorbed on
$\mathrm{Cu}^{0} / \mathrm{AC}$ surface [27]. The calculated results indicated that DMC forms in the reaction of MMC with methanol.

Another theoretical analysis demonstrated that on $\mathrm{Cu}_{2} \mathrm{O}(111)$ surface the $\mathrm{CH}_{3} \mathrm{O}$ inhibit the $\mathrm{CO}$ adsorption together with the $\mathrm{CO}$ insertion to methoxide species for the production of MMC. Eventually the main reaction pathway is the reaction of these species with methoxy to form DMC [53].

The present paper supports a recent assumption in the literature for the DMC synthesis, namely that which emphasizes the strong connection with oxidized $\mathrm{Cu}$ as also demonstrated by the results of XPS studies (Fig. 5).

From the above mentioned DMC formation pathways our results verify a few statements, particularly where MMC species react with methanol. The MMC was stated to form by the $\mathrm{CO}$ insertion to the methoxy species however it was not found on the surface during the reaction. It could be explained by the high reactivity and low surface concentration. Still the dissociative adsorption of methanol on $\mathrm{Cu}^{+}$by the formation of methoxy species [44] and the strong $\mathrm{CO}$ adsorption to $\mathrm{Cu}^{+}$[43] were described in the literature.

$\mathrm{Cu}$ oxidization during the reaction was demonstrated by our XPS results (Fig. 5). First mainly $\mathrm{Cu}^{+}$species are formed on the surface, but later the amount of $\mathrm{Cu}^{2+}$ increased in time. As it is illustrated by the DMC formation curve, when only metallic $\mathrm{Cu}$ is on the surface, in the first minutes of the reaction DMC was not produced. Later when only $\mathrm{Cu}^{+}$was detected on the catalyst DMC was also not detectable. By increasing the amount of $\mathrm{Cu}^{2+}$ the DMC formation rate also increased but after some hours it slowly lessened (Fig. 3). The fully oxidized sample was totally inactive in the DMC synthesis. From these results we may conclude that both $\mathrm{Cu}^{+}$and $\mathrm{Cu}^{2+}$ are necessary for the DMC synthesis, and in addition their ratio is decisive in the $\mathrm{DMC}$ formation. The changes of the oxidation state of $\mathrm{Cu}$ during the reaction could result in the changes of the DMC formation rate in time (Fig. 2) on Cu/Norit. Below is a proposed reaction pathway for DMC synthesis in which the following species

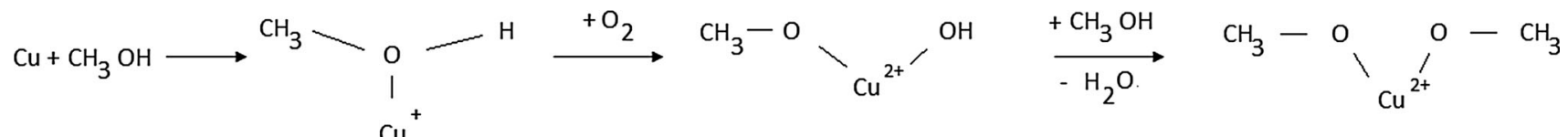

$$
\begin{aligned}
& \mathrm{Cu} \\
& \mathrm{CH}_{3}-\mathrm{O}_{\mathrm{Cu}^{2+}}^{\mathrm{O}}-\mathrm{CH}_{3} \stackrel{+\mathrm{CO}}{\longrightarrow} \mathrm{CH}_{3}-\mathrm{O}_{\mathrm{Cu}^{2+}}^{\mathrm{O}} \underset{\mathrm{O}}{\mathrm{C}}-\mathrm{CH}_{3}
\end{aligned}
$$


have an important role in the first two steps of the reaction. Insertion of CO into the latter species resulted in the DMC formation. Our XPS results support this theory, Zhang and Bell [49] suggested similar mechanism.

The results presented on Fig. 4b strongly suggest that the formation of MF occurs via another possible route. The $\mathrm{O}$ 1s signal of the catalysts indicates that the amount of carboxyl groups increased on the surface during the reaction so the direct interaction of the adsorbed methoxy species with the carboxyl groups could produce the MF.

Methanol adsorption on oxidized $\mathrm{Cu}$ on $\mathrm{CuO}$ surface results in the production of formate species [54] while either reacts with methanol and so MF is formed or decomposes to $\mathrm{CO}_{2}$. These possibilities lead to the MF rate having a maximum as the function of temperature or contact time. The formation of MF and the decomposition or desorption of this product reduce the $\mathrm{Cu}^{2+}$ centers which could reoxidize with oxygen.

\section{Conclusion}

In this work $\mathrm{Cu}, \mathrm{Ni}$ and $\mathrm{Cu}-\mathrm{Ni} / \mathrm{Norit}$ catalysts were prepared, characterised, their catalytic activities were compared in the oxicarbonylation of methanol. Based on the experiments we can conclude the following:

$\mathrm{Cu} /$ Norit was a significantly effective catalyst for DMC synthesis. Under the optimal reaction conditions at atmospheric pressure the highest selectivity of DMC was about $60 \%$ and the highest conversion of methanol was $22 \%$ with the DMC yield of $13.2 \%$ in the steady state of the reaction which is comparable with the previously reported ones at high pressure. The $\mathrm{CO}_{2}$ formation rate was increasing with the temperature while MF and DMC formation rate changed through a maximum curve verifying that $393 \mathrm{~K}$ is the optimal temperature. The formation rate of $\mathrm{DMC}$ and $\mathrm{CO}_{2}$ linearly enhanced by changing the contact time the formation rate of MF went through a maximum which is supposed to be the by-product of the reaction.

The XPS measurement results revealed that $\mathrm{Cu} /$ Norit catalyst went through changes. After reduction the catalyst was oxidized in the reaction, furthermore, the ratio of $\mathrm{Cu}^{+}$ and $\mathrm{Cu}^{2+}$ was determining in the DMC formation rate. The $\mathrm{C}$ 1s peak showed no significant change on the surface of the catalyst but from the $\mathrm{O} 1 \mathrm{~s}$ spectra the change of the carbon and $\mathrm{O}_{2}$ content was visible.

Acknowledgments Financial support of this work by TAMOP 4.2.2.A-11/1/KONV-2012-0047 and HU RO/0901/090/2.2.2 project is gratefully acknowledged. This research was supported by the European Union and the State of Hungary, co-financed by the European Social Fund in the framework of TAMOP-4.2.4.A/2-11/12012-0001 'National Excellence Program'.

\section{References}

1. Li C, Zhang X, Zhang S (2006) Chem Eng Res Des 87:1

2. Wen LB, Xin CY, Yang SC (2010) Appl Energ 87:115

3. Shivarkar AB, Gupte SP, Chaudhari RV (2005) J Mol Catal A 226:49

4. Ono Y (1997) Appl Catal A 155:133

5. Tharun J, Dharman MM, Hwang Y, Roshan R, Park MS, Park DW (2012) Appl Catal A 419:184

6. Li Z, Su K, Cheng B, Ming J, Zhang L, Xu Y (2011) Catal Commun 12:932

7. Litaiem Y, Dhahbi M (2012) J Mol Liq 169:54

8. Kim I, Ahn JT, Ha CS, Yang CS, Park I (2003) Polymer 44:3417

9. Seong P, Jeon BW, Lee M, Cho DH, Kim D, Jung KS, Kim SW, Han SO, Kim YH, Park C (2011) Enzyme Microb Technol 48:505

10. Giannoccaro P, Ravasio N, Aresta M (1993) J Organomet Chem 451:243

11. Keller N, Rebmann G, Keller V (2010) J Mol Catal A 317:1

12. Zhang B, Ding G, Zheng H, Zhu H (2014) Appl Catal B 152:226

13. Tomishige K, Sakaihori T, Ikeda Y, Fujimoto K (1999) Catal Lett $58: 225$

14. Jiang CJ, Guo YH, Wang CG, Hu CW, Wu Y, Wang EB (2003) Appl Catal A 256:203

15. Wang XJ, Xiao M, Wang SJ, Lu YX, Meng YZ (2007) J Mol Catal A 278:92

16. Tomishige K, Kunimori K (2002) Appl Catal A 237:103

17. Stoica G, Abelló S, Ramírez JP (2009) Appl Catal A 365:252

18. Sun J, Yang B, Wang X, Wang D, Lin H (2005) J Mol Catal A 239:82

19. Han MS, Lee BG, Suh I, Kim HS, Ahn BS, Hong SI (2001) J Mol Catal A 170:225

20. Han MS, Lee BG, Ahn BS, Kim HS, Moon DJ, Hong SI (2003) J Mol Catal A 203:137

21. Liu T, Chang CS (2007) J Chin Inst Chem Eng 38:29

22. Ren J, Guo C, Yang L, Li Z (2013) Chin J Catal 34:1734

23. Jiang R, Wang S, Zhao X, Wang Y, Zhang C (2003) Appl Catal A $238: 131$

24. Bian J, Xiao M, Wang S, Lu Y, Meng Y (2009) Appl Surf Sci 255:7188

25. Merza G, László B, Oszkó A, Pótári G, Baán K, Erdőhelyi A (2014) J Mol Catal A 393:117

26. Bian J, Wie XW, Wang L, Guan ZP (2011) Chin Chem Lett 22:57

27. Ren J, Wang W, Wang D, Zuo Z, Lin J, Li Z (2014) Appl Catal A 472:47

28. Barthos R, Solymosi F (2007) J Catal 249:289

29. Barthos R, Széchenyi A, Koós Á, Solymosi F (2007) Appl Catal A 327:95

30. Solymosi F, Barthos R, Kecskeméti A (2008) Appl Catal A 350:30

31. Marbán G, López A, López I, Solís TV (2010) Appl Catal B 99:257

32. Tolmacsov P, Gazsi A, Solymosi F (2009) Appl Catal A 362:58

33. Pótári G, Madarász D, Nagy L, László B, Sápi A, Oszkó A, Kukovecz Á, Erdőhelyi A, Kónya Z, Kiss J (2013) Langmuir 29:3061

34. Madarász D, Pótári G, Sápi A, László B, Csudai C, Oszkó A, Kukovecz Á, Erdőhelyi A, Kónya Z, Kiss J (2013) J Phys Chem Chem Phys 15:15917

35. Nam JK, Choi MJ, Cho DH, Suh JK, Kim SB (2013) J Mol Catal A $370: 7$

36. Wagner CD, Riggs WM, Davis LE, Moulder JF, Mullenberg GE (1992) Handbook of X-ray Photoelectron Spectroscopy, PerkinElmer, USA 
37. Saw ET, Oemar U, Tan XR, Du Y, Borgna A, Hidajat K, Kawi S (2014) J Catal 314:32

38. Guczi L, Stefler G, Geszti O, Sajó I, Pászti Z, Tompos A, Schay Z (2010) Appl Catal A 375:236

39. Figueiredo JL, Pereira MFR, Freitas MMA, Órfão JJM (1999) Carbon 37:1379

40. Polovina M, Babic B, Kaluderovic B, Dekanski A (1997) Carbon 35:1047

41. Puziy AM, Poddubnaya OI, Socha RP, Gurgul J, Wisniewski M (2008) Carbon 46:2113

42. Sánchez MS, Valiente AM, Ruiz AG, Nevskaia DM (2010) J Colloid Interface Sci 343:194

43. Dandekar A, Vannice MA (1998) J Catal 178:621

44. Engeldinger J, Domke C, Richter M, Bentrup U (2010) Appl Catal A 382:303
45. London JW, Bell AT (1973) J Catal 31:32

46. Kar PB, Ramanathan N, Sundararajan K, Viswanathan KS (2012) J Mol Struct 1024:84

47. Bohets H, Veken BJ (1999) Phys Chem Chem Phys 1:1817

48. Wilmhurst JK (1957) J Mol Spectrosc 1:201

49. Zhang Y, Bell AT (2008) J Catal 255:153

50. Wachs IE, Madix RJ (1978) J Catal 53:208

51. Lin SD, Cheng H, Hsiao TC (2011) J Mol Catal A 342:35

52. Camplin JP, McCash EM (1996) Surf Sci 360:229

53. Zhang R, Song L, Wang B, Li Z (2012) J Comput Chem 33:1101

54. Poulston S, Rowbotham E, Stone P, Parlett P, Bowker M (1998) Catal Lett 52:63 